Um felino macho, sem raça definida, de 6 anos, foi atendido no Hospital Veterinário Sena Madureira 2 dias após biópsia excisional, em colega, de 5 tumores subcutâneos em abdômen ventral. Somente um dos tumores havia sido encaminhado para histopatologia, tratando-se de um fibroma. Decorridos 30 dias de admissão ao hospital, observaram-se formaçōes em região de mamas torácicas a inguinais, que foram excisadas no $51^{\circ}$ dia de atendimento. Pelo exame histopatológico, houve 5 neoplasmas distintos: mixoma, mixossarcoma, fibroma, fibrossarcoma e mastocitoma bem diferenciados. Ocorreu recidiva em vários pontos de pele e mamas, motivando outra cirurgia no $90^{\circ}$ dia. A análise histopatológica das 4 formações retiradas acusou um tipo neoplásico semelhante, caracterizado por proliferaçào mesenquimal de células alongadas com moderado grau de anaplasia, embebidas em estroma frouxo mixomatoso com limites imprecisos. Tal proliferação mostrou-se associada ora a reação piogranulomatosa por fio de sutura, ora a infiltrado inflamatório misto com presença de neutrófilos, macrófagos, linfócitos e grande quantidade de mastócitos, sem sinais de invasão de camadas profundas. Com 140 dias de atendimento, o animal veio a óbito com metástases em pele abdominal (quatro), narinas, olhos e ânus, sem que necrópsia fosse realizada por decisão do proprietário. Os procedimentos cirúrgicos no hospital foram precedidos de exames de imagem (radiografia torácica e ultra-sonografia abdominal) que não apontaram metástases. Pesquisando informações de literatura, o presente caso revela-se atípico, pois trata de sarcomas múltiplos claramente nào-infiltrativos e acompanhados de processo inflamatório marcante, em um paciente de meia idade. Essa modalidade de sarcoma, clinicamente e histologicamente incomum, pode guardar semelhança com certo tipo de fibrossarcoma inflamatório humano, com aspecto de pseudotumor, de ocorrência em mesentério e retroperitôneo.

\title{
87 - Osteossarcoma de patela em cão. Relato de caso
}

Selmi, A.L. ${ }^{2}$; Nishiya, A.T. ${ }^{\dagger}$; Moreira, M.A.B.'; Moura, C.A. ${ }^{2}$; Provasi, A. ${ }^{2}$; Eimantas, G.C. ${ }^{2}$; Coelho, H.C.C. ${ }^{3}$; Guerra J.L. ${ }^{4}$
1- Hospital Veterinário Universidade Anhembi-Morumbi, São Paulo-SP

2- Faculdade de Medicina Veterinária da Universidade Anhembi-Morumbi, São Paulo-SP

3- Graduação da Faculdade de Medicina Veterinária Universidade Anhembi-Morumbi, São Paulo-SP

4- Supervisor da Faculdade de Medicina Veterinária da Universidade Anhembi-Morumbi, São Paulo-SP; Departamento de Patologia da Faculdade de Medicina Veterinária e Zootecnia da Universidade de São Paulo, São Paulo-SP

Os osteossarcomas são os tumores ósseos primários mais freqüentes em càes $\left(85^{\circ} \%\right)$. Acometem, na maioria das vezes, animais de médio a grande porte com idade média de 7 anos. $75 \%$ ocorrem no esqueleto apendicular, principalmente nas regiões metafisárias distais de rádio e proximal de úmero. Os osteossarcomas de patela são pouco freqüentes. Foi atendido no Hospital Veterinário da Universidade Anhembi Morumbi, um animal da espécie canina, fềmea, sem raça definida de 10 anos de idade com histórico de claudicaçào de membro pélvico esquerdo há 45 dias. No exame físico, observou-se discreto aumento de volume em regiào patelar esquerda, consistência firme e discreta sensibilidade. $\mathrm{O}$ exame radiográfico (articulaçào fêmoro-tibio-patelar e tórax) evidenciou -se área circular de osteólise nas regiōes média e distal de patela esquerda, com proliferação óssea de aspecto irregular e heterogêneo na sua margem dorsal. Observou-se, também, irregularidade de contorno ósseo. Ao exame radiográfico de tórax não foram encontradas evidências sugestivas de metástases. Realizaram-se exames pré-anestésicos de hemograma, dosagem sérica de creatinina , uréia e eletrocardiograma, que nào contra-indicaram o procedimento cirúrgico. $\mathrm{O}$ animal foi, então, submetido à artrotomia parapatelar medial e patelectomia esquerda. Foi realizado um reforço do tendào patelar com retalho pediculado de fáscia lata. No exame histopatológico, verificou-se tecido ósseo neoformado, aleatoriamente distribuido com osteoblastos proliferados, denotando alto grau de anaplasia, com inúmeras figuras atípicas de mitoses, caracterizando um osteossarcoma patelar. No $7^{\text {? }}$ dia pós cirúrgico, o animal apresentava bom estado geral e apoio do membro pélvico esquerdo ao passo e em estação. 